\title{
EVALUASI KINERJA APARATUR SIPIL NEGARA DALAM PELAYANAN PUBLIK DI KANTOR KECAMATAN LASALIMU SELATAN KABUPATEN BUTON
}

\author{
Mila Muliawati Sapta Juniar Nala ${ }^{1}$, Nastia $^{2}$ \\ ${ }^{1}$ Mahasiswa Program Studi Ilmu Pemerintahan \\ ${ }^{2}$ Dosen Ilmu Pemerintahan
}

Fakultas Ilmu Sosial dan Ilmu Politik, Universtas Muhammadiyah Buton

Email : milamuliawati25@gmail.com

\begin{abstract}
Abstrak
Penelitian ini bertujuan untuk mengetahui Evaluasi Kinerja aparatur sipil negara dalam Pelayanan Publik di Kantor Kecamatan Lasalimu Selatan Kabupaten Buton dengan indikator: kemampuan pegawai dalam menyelesaikan pekerjaan, kualitas pekerjaan yang dihasilkan pegawai, responsibilitas serta disiplin kerja dan faktor-faktor yang mendukung serta menghambat kinerja pegawai. Metode yang digunakan dalam penelitian ini adalah teknik Purposive Sampling analisis data yang digunakan dalam penelitian ini adalah deskriptif kualitatif yang diawali dengan proses pengumpulan data, penyederhanaan data, penyajian data, dan penarikkan kesimpulan.

Kesimpulan dari penelitian ini bahwa Evaluasi Kinerja Pegawai dalam Pelayanan Publik di Kecamatan Lasalimu Selatan Kabupaten Buton belum maksimal sebagaimana mestinya hal ini terlihat dari hasil kerja pegawai, baik dari segi kemampuan pegawai dalam menyelesaikan pekerjaan, kualitas pekerjaan yang dihasilkan pegawai, responsibilitas serta disiplin kerja yang ada di kantor Kecamatan Lasalimu Selatan masih banyak kendala yang dihadapi hal ini disebabkan kurangnya perhatian dari pemerintah kabupaten.
\end{abstract}

Kata kunci : Evaluasi Kinerja,Pelayanan Publik, Kecamatan Lasalimu Selatan

\section{Pendahuluan}

Indonesia didalam memasuki era otonomi daerah sejak ditetapkannya Undang-Undang Nomor 32 Tahun 2004 dan revisi Undang-Undang nomor 23 tahun 2014 tentang Pemerintahan Daerah. Melalui Otonomi, diharapkan daerah akan lebih mandiri dalam menentukan seluruh kegiatannya dan urusan rumah tangganya sendiri serta lebih mendekatkan pelayanan kepada masyarakat. Dalam prakteknya sistem otonomi daerah akan memberi dampak yang positif terhadap peningkatan kualitas pelayanan publik, hal ini dikarenakan : 
a. Otonomi daerah akan memperpendek tingkatan atau jenjang hirarki pengambilan keputusan, sehingga pengambilan keputusan dapat dilakukan secara cepat.

b. Otonomi daerah akan memperbesar kewenangan dan keleluasaan daerah sehingga permintaan daerah kabupaten atau kota dapat merumuskan dan mengimplementasikan kebijakan yang lebih sesuai dengan kebutuhan daerah dan tuntutan masyarakat.

c. Otonomi daerah akan memperdekat penyelenggara pemerintah dengan konstituennya sehingga penyelenggara pemerintah akan dapat merespon tuntutan masyarakat secara lebih tepat.

d. Kedekatan dengan konstituen tersebut juga akan meningkatkan tingkat akuntabilitas penyelenggara pemerintah karena masyarakat lebih dekat dan memiliki akses yang lebih besar untuk mengontrol jalannya pemerintahan." (Ratminto dan Atik Septi Winarsih, 2007 )

Berkenaan dengan hal itu, kepada daerah diberikan kewenang yang lebih besar untuk menyelenggarakan pemerintahan, pembangunan dan pelayanan publik. Hal ini dimaksud agar potensi daerah dapat dioptimalisasikan sebesar- besarnya demi kepentingan dan kesejahteraan masyarakat. Pada era otonomi daerah tuntutan masyarakat terhadap pelayanan semakin meningkat bahkan derasnya tuntutan tersebut menjadikan sebagai kebutuhan yang penting bagi kehidupan sehari-hari dan berharap diperolehnya mutu pelayanan yang lebih baik. Pelayanan merupakan sesuatu yang penting karena hal tersebut berkaitan dengan pengorbanan waktu, tenaga, dan biaya.

Dalam suatu organisasi atau lembaga sangat mengharapkan dan menghendaki suatu tingkat efektivitas kerja yang baik, efektivitas kerja yang baik pada gilirannya akan menghasilkan suatu produktivitas kerja yang optimal. Selain itu yang patut disadari oleh dinas publik atau aparatur tingkat daerah adalah bahwa pelayanan yang mereka berikan bukan hanya bergantung kepada kebaikan pelaksanaan tugas, melainkan juga ditentukan oleh penerima dan kepuasan masyarakat atas pelayanan yang diberikan. Hal ini semua menunjukan tingkat kinerja yang mereka kerjakan. Banyak masyarakat yang masih mengeluh hasil kerja yang diberikan aparatur pemerintah dalam melayani masyarakat. Publik atau masyarakat mengharapkan pelayanan yang cepat, bermutu dan mudah (Sadat, 2016).

Oleh karena itu, kinerja pegawai merupakan salah satu komponen yang perlu untuk ditingkatkan, yaitu bagaimana kinerja seorang pegawai yang ada pada birokrasi dapat lebih memberikan kepuasan pelayanan terhadap orang yang menerima pelayanan tersebut. Dalam rangka peningkatan kinerja, seorang birokrat harus mampu mengembangkan inovasi dan lebih responsive terhadap perubahan yang terjadi dilingkungan masyarakat. Dalam proses peningkatan kinerja perlu didukung dari struktur birokrasi yang harus mampu memberikan ruang gerak kebebasan bertanggung jawab pada birokrat pelaksana untuk mengembangkan kreativitas dan beradaptasi dengan lingkungan yang menyertai pelaksanaan tugas dan fungsinya di lapangan. Untuk mengetahui terlaksana atau tidak tanggung jawab pegawai sudah tentu memerlukan 
Standar Operasional Prosedur Pelayanan (SOP). Standar itulah yang digunakan sebagai acuan, tolak ukur atau perbandingan antara pelayanan yang diterima atau yang dirasakan dengan yang diharapkan.

Hal tersebut diatas merupakan hal-hal yang menjadi keinginan dan cita-cita masyarakat selama ini, di tingkat Kecamatan khususnya masyarakat yang ada di wilayah Kecamatan Lasalimu Selatan Kabupaten Buton. Masyarakat setempat sangat mengharapkan adanya pelayanan prima yang dilakukan oleh aparat Kecamatan Lasalimu Selatan Kabupaten Buton

Namun pada kenyataannya, berdasarkan observasi awal yang peneliti lakukan, pelayanan yang diberikan oleh pegawai atau aparat di Kantor Kecamatan Lasalimu Selatan Kabupaten Buton masih jauh dari harapan masyarakat. Hal ini terliat dari beberapa masalah yang penulis amati seperti pihak Kecamatan melayani masyarakat belum optimal, hal ini terbukti dari masih kurangnya kualitas pelayanan yang dirasakan oleh masyarakat, seperti surat-surat keterangan atau pengantar yang diperlukan masyarakat masih terlihat lambat karena sering menunda-nunda penyelesaian urusan yang menjadi keperluan masyarakat. Masyarakat ingin atau menuntut untuk diberikan pelayanan yang terbaik dan berkualitas. Artinya masyarakat ingin dilayani dengan cepat, mudah, bermutu, ramah, nyaman, transparan, serta prosedur pelayanan yang tidak berbelit-belit yang diberikan oleh pihak kecamatan.

Selain itu tingkat disiplin yang kurang diterapkan oleh pegawai juga merupakan masalah utama yang dihadapi masyarakat saat berurusan di Kantor Kecamatan, karena pada saat masyarakat mengharapkan untuk mendapatkan pelayanan, sering terjadi pegawai atau aparat yang berkaitan tidak ada ditempat untuk melayani masyarakat. Berdasarkan uraian diatas maka penulis tertarik untuk melakukan penelitian dengan judul "Evaluasi Kinerja Aparatur Sipil Negara Dalam Pelayanan Publik di Kantor Kecamatan Lasalimu Selatan Kabupaten Buton ".

\section{Metode Penelitian}

Dalam penelitian ini, penulis menggunakan penelitian deskriptif kualitatif, Menurut Arikunto (2005:234) mengatakan bahwa penelitian deskriptif kualitatif merupakan penelitian yang dimaksudkan untuk mengumpulkan informasi mengenai status gejala yang ada, yaitu keadaan gejala yang dikumpulkan di lapangan menurut apa adanya pada saat penelitian dilakukan. Tehnik Pengumpulan Data dalam penelitian ini adalah Studi Kepustakaan (Library Research), dan Penelitian Lapangan (Field Work Research). Untuk menganaliasa data kualitatif menurut Miles dan Michael (2007:20), analisa data kualitatif terdiri dari 4 komponen, antara lain Pengumpulan data, Data reduction/penyederhanaan data, Penyajian data, dan Penarikan kesimpulan. 


\section{Hasil Penelitian Dan Pembahasan}

\section{a. Kinerja Pegawai Kantor Kecamatan Lasalimu Selatan}

Pegawai kantor Kecamatan merupakan tulang punggung dari pelaksanaan pemerintah di kecamatan. Hal ini berarti berhasil tidaknya segala kegiatan di kantor kecamatan adalah tanggung jawab dari pegawai Kecamatan. Untuk itu perlu adanya peningkatan mental pegawai yang ada dalam hal ini adalah tanggung jawab dari Camat selaku pimpinan tertiggi di pemerintahan Kecamatan. Sebagai pimpinan seorang camat harus mampu memimpin bawahannya dengan baik, memberi motivasi, dan mampu mengarahkan agar para bawahannya tersebut.

Bekerja secara profesional dan penuh akuntabilitas dalam melaksanakan tugastugas pelayanan masyarakat. Kinerja menurut Mangkunegara ( $2001: 67$ ) adalah hasil kerja secara kualitas maupun kuantitas yang dicapai oleh seorang pegawai dalam melaksanakan tugas sesuai dengan tanggung jawab yang diberikan kepadanya. Berdasarkan pengertian ini maka yang menjadi tolak ukur dalam penilaian kinerja adalah hasil, baik itu secara kualitatif maupun kuantitatif. Hal ini sangat dipengaruhi oleh produktivitas, kualitas layanan dan disiplin dari pegawai itu sendiri.

\section{b. Kemampuan Pegawai dalam Menyelesaikan Pekerjaan.}

Kemampuan pegawai dalam menyelesaikan pekerjaan merupakan salah satu faktor yang sangat menentukan dalam keberhasilan suatu pelayana yang diberikan oleh pegawai kepada masyarakat. Kemampuan pegawai dalam menyelesaikan pekerjaan dalam hal pelayanan publik merupakan salah satu hal yang harus dimiliki oleh seorang pegawai dan tuntutan dalam melaksanakan pekerjaan sesuai dengan kewajiban dan tugas sebagai seorang pegawai yang tugas pokoknya dalah memberikan pelayanan kepada masyarakat.

Kemampun menyelesaikan pekerjaan ini dapat dilihat dari apakah setiap tugas pokok dan fungsinya dapat diselesaikan sesuai standar yang telah ditetapkan. Apabila seorang pegawai dapat menyelesaikan pekerjaan sesuai dengan waktu atau tepat waktu maka kinerja pegawai tersebut dapat dikatakan baik artinya pegawai tersebut dapat memberiakan pelayanan dan melaksanakan tugasnya sesuai dengan target waktu yang telah ditentukan baik oleh standar atau aturan yang telah ditentukan ataupun batasan waktu yang telah ditetepkan atau diberikan oleh atasan. Kemampuan pegawai Kantor Kecamatan Lasalimu Selatan Kubupaten Buton dalam menyelesaiakan pekerjaan sudah cukup baik, hal ini juga didukung dengan kemapuan pegawai itu sendiri.

\section{c. Kualitas Pekerjaan yang di Hasilkan Pegawai.}

Kualitas merupakan salah satu cara untuk mengetahui tinggi rendahnya kinerja pegawai, yang mana dapat dilihat sejauh mana kinerja pegawai dapat menyelesaikan pekerjaan dengan kualitas atau mutu yang baik. Kualitas hasil pekerjaan para pegawai 
dapat dilihat dari kerapian kerja dan ketelitian kerja atau tingkat kesalahan yang dilakukan oleh pegawai dalam melakukan atau melaksanakan suatu tugas atau pekerjaan.

Berdasarkan data yang diperoleh dilapangan dan dari hasil wawancara penulis bahwa kualitas yang dihasil pegawai sudah cukup baik namun belum seluruhnya menghasilkan kualitas sesuai yang diharapkan ini dikarenakan kurang rasa tanggung jawab terhadap pekerjaannya sehingga masih sering adanya kesalahan yang dilakukan oleh pegawai seperti dalam pengetikan surat keterangan dan lain-lain ada kalimat yang tertinggal yang mengakibatkan tertundanya urusan masyarakat karena surat keterangan tersebut harus diketik ulang oleh pegawai Kecamatan Lasalimu Selatan.

\section{Responsibilitas}

Responsibilitas dirasakan masih belum bisa dikatakan baik karena pegawai di kantor Kecamatan Lasalimu Selatan ini sering kali tidak memperhatikan peraturan yang ada, sering kali pegawai melanggar peraturan yang bertolak belakang dengan teori yang sebenarnya menurut Lenvine dalam Dwiyanto (2006: 51) yang menjelaskan apakah pelaksanaan kegiatan birokrasi publik itu dilakukan sesuai dengan prinsip- prinsip administrasi yang benar dengan kebijakan birokrasi, baik yang eksplisit maupun implisit. Responsibilitas pegawai Kantor Kecamatan Lasalimu Selatan Kabuapten Buton belum bisa dikatakan baik hal ini dapat dilihat dari beberapa pegawai yang suka meninggalkan pekerjaan pada saat jam kerja kantor. Seharusnya pegawai lebih memperhatikan peraturan yang ada dan bertanggungjawab atas pekerjaan yang diembankan oleh pegawai tersebut agar pelayanan kepada masyarakat berjalan dengan maksimal sesuai misi dari Kecamatan Lasalimu Selatan.

\section{Disiplin Pegawai}

Disiplin merupakan suatu sikap untuk bertindak sesuai dengan ketentuan atau norma yang berlaku dilingkungan organisasi. Disiplin merupakan suatu sikap kewajiban yang dimiliki oleh seseorang untuk mengikuti atau mematuhi peraturan-peraturan standar yang berlaku dalam lingkungan organisasi. Dengan kata lain, kedisiplinan pegawai adalah suatu bentuk pelatihan yang berusaha memperbaiki dan membentuk pengetahuan, sikap dan perilaku seseorang sehingga dapat meningkatkan semangat kerja pegawai. Disiplin pegawai terhadap jam kerja kantor berpengaruh langsung terhadap pelaksanaan atau penyelesaian tugas dan pekerjaan pegawai yang akhirnya berdampak pada pelayanan yang diterima masyarakat Kecamatan Lasalimu Selatan .

Berdasarkan data yang diperoleh dilapangan dan dari hasil wawancara bahwa disiplin kerja pegawai Kecamatan masih kurang baik ini dapat dilihat dari beberapa pegawai kantor Kecamatan yang masih sering terlambat kerja, meninggalkan tempat kerja tanpa alasan yang jelas dan pulang sebelum pada waktunya. Hal ini membuktikan bahwa disiplin pegawai kantor masih perlu ditingkatkan. 


\section{d. Faktor Penghambat dan Faktor Pendukung Kinerja Pegawai di Kantor Kecamatan Lasalimu Selatan .}

\section{Faktor Penghambat}

a. Kurangnya perhatian terhadap kualitas layanan pegawai kepada masyarakat. Kinerja pegawai dapat dilihat dari kualitas pekerjaan yang dihasilkan oleh masing-masing pegawai pada bidangnya. Kualitas personal pegawai dikantor kecamatan masih kurang baik ini terlihat saat masyarakat sedang berurusan di kantor kecamatan dalam pembuatan KTP dan surat menyurat lainnya, dalam pengetikan nama dan tanggal lahir masih sering terjadi keslahan pembuatan nama dan tanggal lahir. Seorang pegawai dituntut untuk dapat mengerjakan tugas secara rapi dan teliti supaya tidak terjadinya kesalahan dalam pengetikan nama dan tanggal lahir, sehingga kualitas layanan yang baik dapat terwujud.

b. Ketidak disiplinan pegawai dalam menjalankan tugas. Tingkat disiplin kerja sebagai pegawai dikantor Kecamatan Lasalimu Selatan kurang maksimal, masih ada pegawai yang datang terlambat kekantor sehingga membuat masyarakat yang membutuhkan pelayanan menjadi menunggu. Hal seperti ini dapat menghambat kinerja pegawai dalam memberikan pelayanan kepada masyarakat menjadi kecewa dengan pelayanan yang diberikan oleh kantor kecamatan.

\section{Faktor Pendukung}

a. Insentif Pegawai

Insentif pegawai merupakan suatu imbalan yang diterima oleh pegawai sebagai balas jasa atas kerja yang telah dilakukan. Pemberian insentif biasaya dikasih kepada pegawai agar para pegawai termotivasi dalam bekerja atau melaksanakan tugasnya sehingga dapat menghasilkan disiplin dan kualitas pegawai yang tinggi dalam melayani masyarakat.

b. Sarana dan Prasara.

Dalam kinerja sangatlah dibutuhkan sarana dan prasaran yang mendukung sehingga kinerja pegawai dapat berjalan dengan maksimal. Sarana dan prasaran yang ada dikantor kecamatan Lasalimu Selatan cukup memadai dan sudah sangat membantu pegawai dalam meningkatkan kinerjanya dalam bekerja dan melayani masyarakat.

\section{Kesimpulan}

Berdasarkan penyajian data dan pembahasan yang telah diuraikan dari fokus penelitian yaitu kemampuan pegawai dalam menyelesaikan pekerjaan, kualitas pekerjaan yang dihasilkan pegawai, responsibilitas serta disiplin kerja dan faktor-faktor 
penghambat serta pendukung kinerja pegawai dalam pelayanan publik di Kantor Kecamatan Lasalimu Selatan, maka penulis dapat menarik kesimpulan sebagai berikut :

1. Kemampuan pegawai dalam menyelesaikan pekerjaan di Kantor Kecamatan Lasalimu Selatan dapat diukur dari tingkat hasil kerja pegawai, tingkat prestasi kerja dan hasil kerja pegawai dalam memberikan pelayanan kepada masyarakat. Pihak kecamatan berusaha memberikan pelayanan kepada masyarakat dengan baik artinya pegawai sudah memberikan pelayanan kepada masyarakat sesuai dengan apa yang masyarakat inginkan. Hal ini menunjukkan bentuk pelayanan pegawai sudah menujuh kearah yang lebih baik.

2. Kualitas pekerjaan yang di hasilkan Pegawai Kecamatan Lasalimu Selatan dalam memberikan pelayanan kepada masyarakat dapat diukur dari tingkat kepuasan masyarakat. Masyarakat menilai hasil kerja pegawai sudah cukup baik, namun masih belum sepenuhnya menghasilkan kualitas yang sesuai yang diharapkan masyarakat, karena masih ada beberapa kekurangan yang harus diperbaiki seperti masalah waktu pemberian layanan yang memakan waktu lama dalam menyelesaikan tugasnya.

3. Responsibilitas merupakan seberapa patuh pegawai yang bekerja pada kantor Kecamatan Lasalimu Selatan Kabupaten Buton, dari hasil penelitian menunjukan bahwa sebagian pegawai yang kurang memperhatikan atau mengabaikan peraturan tersebut sehingga sering melanggar peraturan yang ada. Responsibilitas di kantor Kecamatan perlu ditingkatkan.

4. Disiplin pegawai kantor Kecamatan Lasalimu Selatan masih perlu ditingkatkan. Kurangnya kesadaran individu tentang disiplin kerja sangat mempengaruhi kinerja pegawai di Kantor Kecamatan Lasalimu Selatan. Hal ini terjadi karena atasan atau pimpinan yang tidak tegas dan lemahnya sanksi yang diberikan terhadap pegawai yang masih sering melakukan pelanggaran seperti pegawai masih sering terlambat kerja, meninggalkan tempat kerja tanpa alasan yang jelas dan pulang sebelum pada waktunya.

5. Diketahui bahwa faktor-faktor yang menjadi penghambat kinerja pegawai dalam memberikan pelayanan kepada masyarakat, yaitu kurangnya perhatian terhadap kualitas layanan pegawai terhadap ketelitian dalam pengetikan urusan surat menyurat terhadap tugas yang diembannya, ketidak disiplinan pegawai dalam menjalankan tugas, dan kurangnya ketrampilan pegawai dalam menjalankan tugas yang diberikan. Sedangkan yang menjadi faktor-faktor pendukung kinerja pegawai dalam memberikan pelayanan kepada masyarakat, yaitu insentif pegawai dan sarana dan prasarana yang ada di Kantor Kecamatan Lasalimu Selatan. Hal tersebut diketahui berdasarkan penelitaian yang dialkukan penulis di Kantor Kecamatan Lasalimu Selatan . 


\section{Referensi}

Arikunto, Suharsini, 2005. Manajemen Penelitian. Rineka Cipta, Jakarta.

Keban, Yaremis T. 2004. Indikator Kinerja Pemda: Pendekatan Manajemen dan Kebijakan. Yogyakarta.

Kurniawan, Agung. 2005. Transformasi Pelayanan Publik. Pembaruan, Yogyakarta.

Lukman, Sampara dan Sugiyanto, 2001. Pengembangan Pelaksanaan Pelayanan Prima. Lembaga Administrasi Negara, Jakarta.

Mahmudi, 2005. Manajemen Kinerja Sektor Publik. UPP AMP YKPN, Yogyakarta.

Mangkunegara, Anwar Prabu, 2005. Evaluasi Kinerja SDM. Repika Aditama, Bandung.

Miles, Mathew. B dan A. Michael Huberman.2009. Analisis Data Kualitatif. Universitas Indonesia (UI-press), Jakarta.

Moenir, A.S. 2001. Manajemen Pelayanan Umum di Indonesia. Bumi Aksara, Jakarta.

Mulyono, Deddy, 2005. Metodologi Penelitian Kualitatif - Paradigma Baru Ilmu Komunikasi dan Ilmu Sosial Lainnya, PT. Remaja Rosdakarya, Bandung.

Sadat, A. (2016). Sinergi Birokrasi, Swasta Dan Masyarakat Dalam Proses Formulasi Kebijakan Perencanaan Pada Bappeda Dan Penanaman Modal Kabupaten Buton. Kybernan: Jurnal Studi Kepemerintahan, 1(2), 18-37.

Sedarmayanti, 2003. Good Governance (Kepemerintahan Yang Baik) Dalam Rangka Otonomi Daerah. Mandar Maju, Bandung.

Simamora, Henry. 2004. Manajemen Sumber Daya Manusia. Edisi Ke-3. STIE YKPN. Yogyakarta.

Sinambela, Lijan Poltak.dkk.2006. Reformasi Pelayanan Publik, Teori, Kebijakan Dan Implementasi. Bumi Aksara, Jakarta.

Sugiyono. 2009. Memahami Penelitian Kualitatif. Alfabeta : Jakarta.

Tika, Moh. Pabundu, 2006. Budaya Organisasi dan Peningkatan Kinerja Perusahaan. Bumi Aksara, Jakarta. 